\title{
Small Comrades as Historians and Ethnographers: Performativity, Agency, and the Socialist Pedagogy of Citizenship in Ceaușescu's Romania, 1969-1989
}

\section{Diana Georgescu}

Throughout the 1970s and 1980s, a time when the appeal of Boy Scout activism and patriotism had significantly waned in the West, thousands of Romanian pioneers were hiking on steep mountain routes in the Carpathians in search of adventure, exploration, and friendship. Playing assigned roles of historians and archeologists of their country's past or ethnographers of peasant life, youths of ten to fourteen joined the growing number of pioneer teams organized by schoolteachers around the country in response to a state-sponsored campaign to promote "purposeful" and patriotic tourism for youth in the late 1960s.' Decades after the collapse of Nicolae Ceaușescu's widely-resented regime, former teachers remember their involvement in summer expeditions fondly, working to continue the tradition of patriotic youth mobilization in the post-socialist context. Former child participants like Marian, who joined his school's team as a teen in 1978, similarly recall their collective experiences with palpable enthusiasm: "[The expedition] had the effect of a drug. After we returned, our gang (gaşcă) would often get together in the summer break. We would meet in the evenings and tell the same stories over and over again. We practically relived the expedition for the rest of our summer break and we stayed friends."

This article starts from the apparent paradox that a state-promoted project to raise patriotic citizens enjoyed significant appeal among children and teachers during late socialism, a historical conjuncture typically described in scholarship in terms of widespread political apathy,

' The term was proposed in Anne Gorsuch and Diane Koenker, Turizm: the Russian and East European Tourist under Capitalism and Socialism (Ithaca, 2006), 8.

'Marian, interview, Bucharest, December 2009. Marian was the team's geologist. The interviews with former expedition participants referenced in this article were conducted by the author between 2009 and 2013 . To ensure anonymity, I use initials or pseudonyms for interviewees who did not specifically require to be named in my work. 
cynicism, and disillusionment. ${ }^{3}$ To unravel this seeming paradox and question the static picture of late socialist society underpinning such accounts, I focus on Expediţille Cutezătorii (The Expeditions of the Daring), a nation-wide competition that successfully mobilized teams of urban and rural youths on summer expeditions from 1969 through 1989. The competition did not lack in ambition, aiming to instill in young people love for the motherland, a spirit of camaraderie, and a scientific worldview by turning them into "purposeful" tourists. Organized as a socialist competition, Expediţiile Cutezătorii pit teams from around the country against each other. Pioneer groups who underwent demanding summer expeditions that lasted three weeks and followed strict rules of self-management could compete in fields ranging from history and ethnography to geography, geology, botany, and ecology. The competition featured a national jury of prominent cultural figures, including historians, ethnologists, writers, journalists, and youth activists, who assessed the scientific and patriotic success of competing teams on the basis of diaries and research collections.

Launched by the Pioneer Organization, Expediţile Cutezătorii was heavily advertised in schools and the pioneer press, prompting not only the creation of teams, but also of tourism and science clubs that served as the basis for year-long physical and scientific training in chosen fields. Indicating that the number of teams increased steadily from a mere two hundred in the early 1970s to an average of two thousand by the late 1970s, the pioneer press concluded in 1988 that the competition had become "a mass social phenomenon, [...] mobilizing approximately thirty thousand teams and over half a million pioneers to date." ${ }_{4}$ The competition was hardly the mass phenomenon clamored for by the official press, but the fact that it engaged approximately $10 \%$ of schoolchildren over two decades, without being a mandatory pioneer activity, is nevertheless suggestive of its popularity. While distinctive in its multivalent appeal, Expediţiile Cutezătorii was not essentially different from other elective pioneer activities - whether school

${ }^{3}$ For studies of late socialism emphasizing the regime's cynicism and resulting political apathy, see, for example, Vladimir Tismaneanu, Reinventing Politics: Eastern Europe from Stalin to Havel (New York, 1993) or Gail Kligman, The Politics of Duplicity: Controlling Reproduction in Ceausescu's Romania (Berkeley, 1998).

"Ion Vlăduţiu, "Argument," in Expediţiile Cutezătorii, şcoală a iubirii de patrie (Bucharest, 1988), 12. See also Cutezătorii, November 13, 1975, as well as the issues of January 31, 1985 and January 30, 1986. 
trips and camps or science and culture clubs and competitions - and can thus illuminate a broader pattern of engagement between socialist citizens and the regime's youth policies.

Exploring how and why pioneer expeditions proved so meaningful, memorable, and empowering for child and adult participants, this article argues that we should depart from traditional representations of the relationship between citizens and the late socialist state in oppositional terms that emphasize resistance, subversion, and indifference, leaving historical subjects strangely disconnected from their socio-political context. If the totalitarian paradigm dominating Cold War scholarship emphasized state oppression and portrayed socialist citizens as devoid of individuality and alienated from fellow citizens by fear, more recent scholarship has understandably focused on forms of resistance and human agency. ${ }^{6}$ Since the 1990 s, countless studies have reinvested socialist citizens with agency, be these dissident intellectuals, students, and workers engaged in underground resistance, ordinary citizens wielding the weapons of everyday subversion, or unofficial cultures evading ideological rigors in alternative milieus.? In pitting socialist citizens against the state, some of these studies portray essentially dehistoricized subjects, who seem unencumbered by social and ideological determinations in their dissenting, self-serving, or escapist relation with the socialist regime. ${ }^{8}$ Whether they challenge the regime

\footnotetext{
Statistics and reports on forms of school tourism (trips, excursions, expeditions) indicate they involved a growing number of school children from the 1960s through the 1980s. Archive of the Romanian Pioneer Organization [hereafter ARP], files 7/1967, 171-9 (Informare privind desfăşurarea vacanţei de vară); 23/1971, 111-6 (Referat asupra evoluţiei cuprinderii pionierilor şi şcolarilor in tabere şi alte acţiuni de vacanţă); 13/1977, 174-6 (Notă cu privire la unele problem ale activitaţii Organizaţiei Pionierilor); and 19/1984, 64-7 (Raport privind activitatea educativă desfăşurată in cadrul acţiunilor turistice). The file and page numbers indicate the original archival references of the Romanian Pioneer Organization. The collection had not been processed and catalogued when I conducted my research in 2009/2010. Because it was temporarily held in the basement of the former Pioneer Palace (now, National Children's Palace) in Bucharest, I obtained permission from the director of the Palace to consult the collection.

'See, for example, classic texts such as Carl J. Friedrich and Zbigniew K. Brzezinski, Totalitarian Dictatorship and Autocracy (Cambridge, Mass., 1965). For an analysis of totalitarianism in Western Cold War literature, see Abbott Gleason, Totalitarianism: The Inner History of the Cold War (New York, 1995).

Scholarship on dissidence centers on Poland, Czechoslovakia, and Hungary and includes Barbara Falk, The Dilemmas of Dissidence in East-Central Europe: Citizen Intellectuals and Philosopher Kings (Budapest, 2002); Tismaneanu, Reinventing Politics; Kevin McDermott and Matthew Stibbe, eds., Revolution and Resistance in Eastern Europe: Challenges to Communist Rule (Oxford, 2006). For a recent study on forms of evasion and escape, see Cathleen Giustino, Catherine J. Plum, and Alexander Vari, eds., Socialist Escapes: Breaking Away from Ideology and Everyday Routine in Eastern Europe, 1945-1989 (New York, 2013).

: The exception to this approach is the burgeoning literature on everyday life, leisure, and consumption, which focuses on particular social categories (women, workers, peasants, etc.) and their forms of accommodation with the regime. See, Paulina Bren and Mary Neuburger, eds., Communism Unwrapped: Consumption in Cold War Eastern
} 
out of moral and political conviction, exploit it for material self-interest, or evade its constraints out of sheer indifference and apathy, the socialist subjects in these studies can only acquire agency from a position opposed to the regime and thus seemingly external to it. ${ }^{\circ}$

Approaching late socialist citizens as inescapably embedded in Ceaușescu's regime, this article claims that children and their adult mentors found self-fulfillment not only by opposing the regime or escaping into alternative lifestyles, but also by engaging directly with state structures and pursuing some of the inextricably-linked socialist and national values the regime promoted..$^{10}$ This active engagement was made possible by the multivalent character of statepromoted projects such as Expeditiile Cutezătorii, which reflected the ambivalent nature of socialist ideology in Ceauşescu's Romania, making room for multiple motivations and interpretations. Some ambiguities, such as the tension between spontaneity and discipline or individualizing and homogenizing tendencies in youth education, were inherent in MarxistLeninist ideology." While most literature focuses on the disciplining and homogenizing aspects of socialist education, this article explores its individualizing potential, arguing that various forms of youth agency were built into the socialist pedagogy of citizenship, which encouraged activism, voluntarism, leadership, and scientific positivism in youth. ${ }^{12}$ Other sources of ambivalence emerged in the late 1960s with Ceauşescu's legitimation of prewar national

Europe (New York, 2012); David Crowley and Susan E. Reid, eds., Pleasures in Socialism: Leisure and Luxury in the Eastern Bloc (Evanston, Ill., 2010); and Shana Penn and Jill Massino, eds., Gender Politics and Everyday Life in State Socialist Eastern and Central Europe (New York, 2009). Even some of the contributions to these volumes, such as the studies on the second economy, assume that the overriding motivation of socialist citizens was (material) self-interest and that citizens could not resonate with socialist values.

- In addition to running the risk of overestimating resistance, this approach rests on a normative liberal notion of subjectivity premised on the dichotomy between an authentic self, relegated to the private sphere, and a public persona compliant with the socialist regime. For a discussion of the pervasiveness of this liberal model in the scholarship on Cold War eastern Europe, see Anna Krylova, "The Tenacious Liberal Subject in Soviet Studies," Kritika: Explorations in Russian and Eurasian History 1, no 1 (Winter 2000): 132, 140-44.

"If engagement is addressed in scholarship on state socialism, it is often framed in negative terms as "complicity" or "conformity," an approach that rests on the view that socialist regimes were essentially immoral systems and any acceptance of their values was a form of material self-interest and/or moral capitulation. The most influential text is Vaclav Havel's 1978 samizdat "The Power of the Powerless," later published with John Keane as The Power of the Powerless: Citizens against the State in Eastern Europe (London, 1985).

"On the ambivalent character of socialist ideology and youth policies, see Alexei Yurchak, Everything Was Forever, Until It Was No More: The Last Soviet Generation (Princeton, 2006), 11, and Juliane Fürst, Stalin's Last

Generation. Soviet Post-War Youth and the Emergence of Mature Socialism (Oxford, 2010), 341.

${ }^{2}$ For scholarship addressing the homogenizing and constraining aspects of youth education, see Katalin Jutteau, L'enfance Embrigadée Dans La Hongrie Communiste: Le Mouvement Des Pionniers (Paris, 2007); Anna Saunders, Honecker's Children: Youth and Patriotism in East(ern) Germany, 1979-2002 (Manchester, 2007); Karin Taylor, Let's Twist Again: Youth and Leisure in Socialist Bulgaria (Münster, 2006). 
discourses, which "disrupted" the ideology of Marxism-Leninism with their emphasis on ethnonational traditions and identity. ${ }^{13}$

To investigate young people's engagement with the socialist regime, this article proposes a performative approach, arguing that socialist nationhood was not something that children merely acquired through instruction, but something they did, something they performed routinely and often inconspicuously in daily life. Whether they covered a nationalized landscape by foot, lived life in the collective, played expert roles of historians, archeologists, and ethnographers of the nation's origins, or wrote expedition diaries, early teens were constituted as national and socialist subjects. Exploring children's everyday performances of socialist patriotism, this work contributes to studies of nationalism that seek to move beyond essentialist and substantialist treatments of nations as real entities by providing investigations of how the (socialist) nation was "powerfully realized in practice." ${ }_{14}$

Performative approaches can further invigorate studies of childhood and youth under authoritarian regimes. In his ethnography of the Little Red Pioneers in contemporary China, T. E. Woronov draws on Judith Butler's theory of performativity to ask how children are produced as nationalist subjects through ritualized practices. Although countering the view that Chinese nationalism is a top-down phenomenon, Woronov's account of subject formation leaves little room for appropriation or agency. The author contends that children's reiterated practices of social norms are predetermined and constraining, contributing to the consolidation of nationalism..$^{\text {s }}$ By comparison, scholars such as Alexei Yurchak emphasize the enabling character of the post-Stalinist regime of "performativity," which privileged the replication of ideological form over content, arguing that young people's performative engagement with Soviet ideology generated multiple meanings and communities, eventually leading to the collapse of the Soviet

\footnotetext{
${ }^{13}$ For an in-depth analysis of the phenomenon, see Katherine Verdery, National Ideology under Socialism: Identity and Cultural Politics in Ceausescu's Romania, (Berkeley, 1991).

${ }^{14}$ Rogers Brubaker, Nationalism Reframed: Nationhood and the National Question in the New Europe (Cambridge, 1996), 13-22.

is T. E. Woronov, "Performing the Nation: China's Children as Little Red Pioneers," Anthropological Quarterly 80 , no 3 (July 2007): 647-672.
} 
Union. ${ }^{16}$ My approach dovetails nicely with these works, although like Yurchak, I am particularly interested in exploring the simultaneously constraining and enabling character of socialist regimes. Although prescribed by youth organizations with the aim of shaping desirable behaviors and beliefs, adult and child performances on pioneer expeditions were not acts of passive reproduction. Each performance introduced an element of unpredictability, opening the ambiguous socialist ideology to acts of appropriation and resignification. Most importantly, individual child performances had the potential to actualize resources of agency inherent in the socialist pedagogy of citizenship.

This study relies on a wide array of resources, ranging from materials contemporary with the events (collective diaries, photo albums and research collections) to retrospective sources such as interviews. In addition to official archives, I draw on twenty-three expedition diaries, typically written by a child diarist and ranging from fifty to two hundred pages in length, and fifteen individual and group interviews with former participants. Covering much of the 1970s and 1980s, the diaries were "salvaged" by teachers and preserved as testimonies of their professional legacy in school and former pioneer palace archives. ${ }^{17}$ Many were produced by teams that engaged in a record number of expeditions and proved eager to share their memories. ${ }^{18}$ The diaries and interviews document diverse team profiles, ranging from groups from major urban centers to teams from small towns or villages, but the majority were generated by members of award-winning teams, constituting a small sample of the tens of thousands of travelogues and teams involved the competition. While they might not be representative of the experience of the average team in narrow statistical terms, these ambitious teams are strategically positioned to illuminate how and why teachers and their students could engage with the late

\footnotetext{
${ }^{16}$ Yurchak, Everything Was Forever.

"The National Children's Palace was the official headquarters of the competition, where expedition documents were sent to the national jury for evaluation. In his quality of secretary of the national jury, Victor Constantinescu preserved the diaries and photo albums of award-winning teams. He provided me with twelve diaries, indicating that he managed to "salvage" them from protesters who took the Palace by assault in December 1989. My research branched off to locate former participants, taking me to cities and villages (Baia-Mare, Chendrea, Năprad) in Transylvania, where I eventually collected an additional set of eleven diaries.

${ }_{18}$ The interviews focused on teams whose expedition travelogues I could consult to allow for comparisons between contemporaneously recorded and recollected experiences. I also conducted interviews with former participants who posted recollections of pioneer expeditions on public blogs of amateur hikers or alpinists, but could not locate their organizing teachers or expedition diary.
} 
socialist regime in meaningful ways. They serve as an analytical lens that narrows the scope of inquiry to enable us to explore, as if under a magnifying glass, the institutional structures of constraint and possibility engendered by socialist ideology and youth policies. ${ }^{19}$

\section{The Actors of Patriotic and Purposeful Tourism: Motivations and Appropriations}

Initiated in 1969, Expediţiile Cutezătorii came in a long pedagogical tradition of raising loyal citizens through physical exertion and exposure to natural beauty and national heritage. The most immediate model for a pedagogy that linked self-improvement with social and national utility was that of the Soviet Pioneers, which inspired the creation of an analogous children's organization in Romania in 1949. The Romanian Pioneers functioned as the Communist Party's main venue for patriotic, moral, and civic education, engaging children in rituals and ceremonies, socially useful labor, socialist competitions, and pioneer trips or camps. Tourism, understood in utilitarian terms as an effective means of providing physical, scientific, and patriotic education, emerged as an appealing venue of youth socialization.

While it continued the postwar tradition of Soviet inspiration, Expediţiile Cutezătorii was also significantly shaped by new developments triggered by Ceaușescu's rise to power in 1965: the growing nationalization of cultural life, the promotion of tourism as part of a larger campaign for the democratization of leisure, and institutional reforms that encouraged pedagogical experimentation and the enhanced status of the teaching staff. By the mid-1960s, the ranks of the Pioneer Organization had swollen to include over $70 \%$ of schoolchildren, prompting the party leadership to call on teachers to take over the task of children's patriotic education from "inexperienced" youth activists..$^{20}$ Ironically, the proposed educational reforms burdened teachers with rarely-compensated political responsibilities that hailed them as indispensable to the

\footnotetext{
${ }^{19}$ This methodological approach is akin to Carlo Ginzburg's valorization (via Auerbach's work) of Ansatzpunkte, i.e. starting points, in the writing of microhistory. See Carolo Ginzburg, "Latitude, Slaves, and the Bible: An Experiment in Microhistory," Critical Inquiry 31, no 3 (Spring 2005): 666.

${ }^{20}$ In the post-Stalinist atmosphere of social reconciliation of the $1960 \mathrm{~s}$, the call on teachers marked a shift from postwar concerns with their political and ideological loyalty to an acknowledgement of their professional expertise. The shift was gradual: teachers had always been expected to support pioneer activities, but these were initially assigned to youth activists in the 1940s and 50s as many teachers were politically suspect, having been educated in the "old" regime and betraying royalist, bourgeois and extreme-right tendencies.
} 
socialist project. Teachers responded to these measures in diverse ways, whether they participated only perfunctorily in mandatory political activities or sought to appropriate statesanctioned activities for meaningful work with children.

Whatever their strategies, interviews suggest that teachers felt genuinely energized by their enhanced sense of professional and civic importance. The educators' engagement in poorlycompensated extracurricular activities such as summer expeditions hinged increasingly on their assumption of a professional identity and sense of dignity and satisfaction. ${ }^{21}$ Many teachers saw pioneer expeditions as opportunities to advance their careers while fulfilling socialist goals that they genuinely embraced: patriotic and scientific education and the strengthened cohesion of their school collective. The majority were young teachers of physical education, history, geography, and other disciplines, who doubled as tourist guides and pursued hobbies as amateur archaeologists, ethnographers, and hikers during summer vacations.22 They selected children based on enthusiasm and talent from among pupils they met weekly in classes or tourism clubs. Reflecting on this sense of professional fulfillment and communal values, most teachers remember expeditions as meaningful pioneer activities, distinguishing them from requirements they only complied with formally:

Even then [under communism], there were passionate teachers devoted to their calling. We didn't organize pioneer expeditions because they were imposed. Classes in political information (informare politică) were imposed and nobody put their heart and soul into them [laugh], but an expedition or an excursion was different. There was nothing political about it, it was life itself: we were cooking and hiking, it was a true slice of life." ${ }_{23}$

This teacher's claim that expeditions were not "political" or "imposed" projects, but personal choices, indicates the extent to which participants resonated with some of the multivalent messages of the competition, particularly their educational, patriotic, and entertaining character. These perceptions of apolitical agency were possible because, unlike

\footnotetext{
${ }^{21}$ Catriona Kelly noted a similar phenomenon of voluntarist work among schoolteachers in the post-Stalinist Soviet Union, see “"The School Waltz:' The Everyday Life of the Post-Stalinist Soviet Classroom,” Forum for Anthropology and Culture 1 (2004): 108-58.

${ }_{22}$ Alongside college students, young teachers responded readily to the opportunities opened by the development of the "tourism industry," training and working as guides to supplement their income by organizing school trips and excursions. Articles in the national press often addressed this phenomenon, see Rodica Serban, "Studiul si perspectivele turismului impun reconsiderarea profesiei de ghid," Scânteia, January 4, 1968.

${ }^{3}$ A.P., teacher of Romanian in Acâs, Satu-Mare, interview, March 2010.
} 
more highly regimented pioneer activities (mass rallies, rituals and celebrations), expeditions were neither mandatory, nor fully orchestrated by the children's organization. They remained a largely grassroots activity dependent on the motivation, initiative, and social capital (that is their ability to motivate children and parents) of the organizing teachers.

The appeal of pioneer expeditions should also be set in the broader context of the socialist regime's agenda of national reclamation. To overcome the party's lack of popular legitimacy, Ceauşescu inaugurated a new ideological agenda in the late 1960s by integrating the history of the party with a teleological national history whose millennial aspirations of sovereignty and unity were allegedly only fully realized under socialism..$^{24}$ In the sphere of youth socialization, this shift prompted revisions of school curricula to integrate narratives of "class struggle" with "the struggle for national independence" and make room for historical personalities in the growing national pantheon, thus making the study of ethnonational origins, continuity, and unity the priority of history education in the post-Stalinist period. ${ }^{25}$ These revisions also affected the patriotic literature children recited at school celebrations, the historical board games they played at home, and the historical sites, heroes, or events that served as the objects of school trips or scientific expeditions.

Forged out of the ambivalent ideology of the socialist nation, Expediţiile Cutezătorii also strove to balance Marxist-Leninist principles and national values. While expeditions were deemed instrumental in aligning children with a larger collective, the nature of that community shifted uneasily from the contemporary socialist collective to the "immemorial" ethnonational community that many teams actively investigated and celebrated. A similar tension between modernity and tradition emerged as the competition called on teachers to develop children's "scientific worldview" while enhancing their patriotic attachment to "the multi-millennial history of the Romanians" and "the contemporary achievements of the working people." ${ }^{26}$ If politically vigilant youth activists cautioned educators to combat the idealization of the past, the

${ }^{24}$ See Verdery, National Ideology.

${ }^{25}$ Elena Ene et al., Metodica predării istoriei României (Bucharest, 1981), 19-20.

${ }^{26}$ Cutezătorii, April 10, 1975. 
competition itself promoted expeditions as acts of retrieval of an ancient national past, offering awards like "The Dacian Shield" for "extraordinary research in the history of the motherland" or "Mioriţa" for "remarkable collections and studies of ethnography and folklore." ${ }^{27}$ The contradictory nature of this message was reinforced by an actual difference of vision among the authorities involved in the administration and assessment of the competition. If youth activists were more squarely committed to the party line, the prominent cultural figures - historians, ethnographers, geographers - who served on the national jury privileged a "science of the nation," a form of scientific inquiry meant to legitimize the nation and instill patriotism, which had significant precedents and prominent practitioners in the interwar period.$^{28}$

The rehabilitation of prewar national discourses and cultural figures served as a covert critique of the widely-resented hegemony of Soviet models in postwar education. As socialist citizens trained to read shifts in official discourses between the lines, teachers got the message and responded with enthusiasm. ${ }^{29}$ Within the broadened ideological framework of late socialism, passionate educators could pursue more personalized and localized agendas than those envisioned by the Pioneer Organization. Even a cursory look at the choice of expedition routes indicates that teachers privileged research on the national past over explorations of working class heroes or sites of socialist achievements such as factories, mines, or hydroelectric plants. Interestingly, the category of ethnographic expeditions was only introduced by organizers in

\footnotetext{
${ }^{27}$ Ibid. "The Dacian Shield" refers to an enduring myth of ethnonational origins in Romanian culture, holding that present-day Romanians are the descendants of ancient Dacian tribes occupying this territory before the Roman conquest. Variants of this myth, popular with those wishing to emphasize the European character of Romanians, see Romanians as originating from the union of Dacians and Romans. "Mioriţa" is the title of a broadly-popularized folk ballad believed to capture the essence of the Romanian peasant, and by implication of the Romanian people.

${ }_{28}$ In their turn, members of the national jury had diverse professional and ideological trajectories, being divided between those more closely associated with the regime (Dumitru Almas, the regime historian, ethnologists such as the Moscow-educated Ion Vlăduţiu, the Director of the Institute of Ethnography and Folklore in Bucharest, and writers such as Aurel Lecca or Ion Grecea) and scholars with prewar training and allegiances (Gheorghe Focşa, the Director of the Village Museum in Bucharest, who was trained in the interwar tradition of militant sociology initiated by Romanian sociologist Dimitrie Gusti, geographers such as Marcian Bleahu and Ion Pişota, both of whom were well-known college professors at the University of Bucharest, and Constantin Preda, a researcher at the Institute of Archeology).

${ }^{2}$ My interviews abound in portraits of "patriotic" teachers such as that painted in retrospect by a male respondent from Bucharest (b. 1968) in August 2009. His former teacher of geography, Andrei recalled, was a "real patriot," who organized regular school trips to historical sites during the 1970s, exhibited a beautifully-carved wooden bust of medieval ruler Michael the Brave in his living room, tried his hand at patriotic poetry, and had recently called to wish his former student a Happy Great Union Day on the anniversary of the union of Transylvania with the Kingdom of Romania in 1918.
} 
response to the growing interest in folk culture expressed by teachers and their teams, suggesting that the competition encouraged local experimentation and initiative in its early stages in the 1960s and 70s. Ambitious teachers also felt emboldened to pursue their hobbies in national archeology or ethnography by the research agendas of the cultural figures on the national jury, agendas that included archeological projects probing the ancient origins of the Romanians by digging up Dacian and Roman remains, or ethnographic atlases concerned as much with mapping ethnographic diversity as with documenting Romanian continuity in Transylvania. ${ }^{30}$

To these motivations, we should add the opportunities - institutional, financial, and symbolic - opened by the genuine, if short-lived, attempts to legitimize Romanian socialism through the promotion of modern lifestyles and the democratization of leisure and consumption in the 1960s and 70s. Expeditiile Cutezătorii was launched during a state campaign to popularize sports and tourism in schools. In an attempt to make tourism accessible to students, the local councils of the Pioneer organization partly sponsored the competition, ensuring camping and research equipment (tents, sleeping bags), accommodation in tourist facilities, and substantial prizes for winners until the mid-1970s."1 Despite institutional support, child participants still contributed an average of three hundred lei in the late 1970s and four hundred lei in the 1980s, indicating a willingness to invest time and money in summer ventures. ${ }^{32}$ Material incentives waned with the deepening economic crisis in the late 1970s and 80s, when the competition adopted new policies of "self-financing," encouraging pioneers to earn the necessary funds for travel through recycling programs or work in cooperative farms. ${ }^{33}$ In the 1980 s, expeditions increasingly reflected wider social responses to economic scarcity, relying on elaborate networks

\footnotetext{
${ }^{30}$ Constantin Preda's archeological projects and Ion Vlăduţiu's Ethnographic Atlas of Romania, for example, inspired many local schoolteachers in their choice of expeditions routes and goals. Some of these topics, such as the history of wooden churches in Transylvania, remained ideologically risky and teachers often had to contend with the critique and obstruction of local youth activists before they could be vindicated by national awards and recognition from the Bucharest jury.

${ }^{31}$ Until the mid to late 1970s, these included trips in the Soviet bloc in addition to electronic equipment.

${ }^{32}$ The contribution was substantial given that the average net salary throughout the $1970 \mathrm{~s}$ ranged from 1,300 to 2,100 lei and, in the 1980s, from 2,200 to 3,000 lei.

${ }^{33}$ Cutezătorii, May 15, 1980. While industry was still protected by "soft budget constraints," cultural enterprises including some extracurricular programs such as expeditions - were encouraged to partially sustain themselves. See Verdery, National Ideology, 108.
} 
of connections, including local school authorities or parents to ensure accommodation, transport, necessary equipment, and food.

The democratization of leisure also made symbolic room for the representation of expeditions as forms of fun, adventure, and entertainment. For child participants and young teachers, much of the allure of expeditions came from their popularization as "haiduk tourism" or jaunts in nature specifically distinguished from stuffy school environments. ${ }^{34}$ Former adolescent participants recall the thrill of adventure, which correlated with independence from parental authority, as an important incentive. For teens describing themselves as "lonely," "withdrawn," "an only child who was often pampered and sheltered," or even "a klutz," expeditions proved great opportunities to make friends outside formal school environments, pursue romantic interests, and transgress the norms of socialist sociality. If expedition travelogues tend to document approved forms of collective life, interviews with former participants uncover unorthodox forms of sociality. Ranging from late night exchanges of science fiction stories by lantern light, breaking curfew, pulling pranks, coming up with silly nicknames, or failing to accomplish assigned tasks, to experimenting with alcohol, cigarettes and romance, these forms of sociality were often quietly tolerated and rarely visible to authorities.

It would be wrong, however, to conclude that expeditions appealed to young people exclusively as opportunities to evade or resist socialist discipline. Evoking adventure, but also hardiness in the face of adversity, "haiduk tourism" was not essentially incompatible with the established Soviet model of "purposeful turizm" as "self-improving and socially constructive: building knowledge, restoring and strengthening the body, encouraging patriotism.." ${ }^{35}$ Organizing teachers sought to toughen children through exposure to nature and rigorous regimes and to build strong community bonds by removing youth from family environments. Teams were expected to

\footnotetext{
${ }^{34}$ Denoting a whole range of social rebels in the eighteenth and nineteenth century Balkans, "haiduks" were contentious figures in folk culture. They were reclaimed as heroes in the struggle for national and social liberation under various political regimes, including Ceaușescu's Romania. On "turism haiducesc" (haiduk tourism), see "Pionieri pe cararile patriei," Educatia pioniereasca, January 1969, 14.

${ }_{35}$ Anne Gorsuch, All This is Your World: Soviet Tourism At Home and Abroad After Stalin (Oxford, 2011$), 6$.
} 
cover mountain routes by foot, camp in tents, and operate as self-managing collectives (procuring food, cooking, cleaning or providing first aid) ${ }^{36}$

While less ambitious teams treated these rules liberally, those aiming to win national awards flexed their muscles, proud in their ability to meet such exacting demands. Judging by participant reminiscences, the sense of friendship and community resulted as much from unorthodox activities as from approved forms of collective life such as separation from the family, social labor in the service of the team or community, mutual help, and overcoming of obstacles. The roughness of camp life stands out in personal recollections as a source of collective bonding, pride, and accomplishment. Mihai, who participated in an expedition in the 1970s, associated overcoming adversity with friendship and collegiality: "If you saw our photos... a bunch of skinny kids, you'd wonder how we survived! My backpack weighed about ten kilos. It wasn't a spirit of "camaraderie" [tovărășie] or anything, but you simply learned to outperform yourself, reach out to colleagues, make friends and come back home safe and sound. ${ }^{, 37}$ Speaking to me at a time of general derision of the socialist past, Mihai downplayed the role of the official notion of "tovărășie" in order to claim an authentic, rather than stateimposed, sense of friendship. Nevertheless, his language echoed another socialist ideal of "outperforming oneself" in a race to self-improvement, just as his behavior on the expedition replicated social practices of camaraderie encouraged by socialist pedagogy.

Similarly, by envisioning expeditions as opportunities to overcome familial attachments in order to achieve maturity and responsibility, former participants resonated with the official rhetoric on the socialist collective, whose civic bonds were deemed superior to familial relations: "It was a different feeling than in school, where at the end of the day, we would each go home

${ }^{36}$ The guidelines for the organization of the expedition were published annually in Cutezătorii. See, for example, the first set of rules in the journal's issue of May 15, 1969 and slight additions and changes in later regulations in the issue of April 10, 1975.

37 Mihai, interview, Bucharest, November 2009. 
'to mom.' On the expedition, we ended up referring to our tent as 'home.' Returning home meant coming back to the camping area, not to mom." ${ }^{38}$

Another officially-promoted socialist value that mobilized teachers and pioneers was the "educational" character of summer expeditions. Critical of so-called "spontaneous" tourism for its focus on "light entertainment, vacation or happenstance activity," Expediţiile Cutezătorii encouraged goal-driven tourism to "develop our students" scientific view of historical phenomena. ${ }^{39}$ Teachers too saw expeditions as effective strategies of replacing formal school environments with natural surroundings and thus as opportunities for children to learn by doing or by direct experience in both the social and natural sciences.

The prospect of experiential learning also enthused early teens, who were assigned specific duties on the team, playing the roles of captains, diary writers, photographers, ethnographers, archeologists, historians or cooks ${ }^{40}$ From the perspective of socialist pedagogy, role-playing was meant to cultivate young people's activism, leadership, ideological proficiency, scientific worldview and teach them values like initiative, self-reliance, and commitment to the collective. These instances of youth mobilization have long been dismissed in scholarship as enforced forms of homogenization that dissolved the self into an undifferentiated social mass. If youth held any form of agency, it resulted from either opposing disciplining state structures or evading them in alternative milieus. ${ }^{41}$ What gets obscured in these accounts is the individualizing potential of socialist pedagogies, which envisioned teens as small activists with precocious

\footnotetext{
${ }^{38}$ Marian, interview, Bucharest, December 2009.

"Turismul se invata," Educatia pioniereasca, March 1969, 24-26; Mircea Trifu, "Turismul cel de toate zilele," Educatia pioniereasca, August 1968, 44-47. Se also Tatiana Gafan, Metodica predarii istoriei, (Bucharest, 1968), 235.

«o "Expediţiile Cutezătorii,” Cutezătorii, May 15, 1980.

"On the constraining character of pioneer camps in particular, see Catherine J. Plum, "Summer Camp for Socialists: Conformity and Escapism at Camp Mitschurin in East Germany," in Socialist Escapes, 98-126. For literature on socialist education more broadly, see Jutteau, L'enfance Embrigadée; Saunders, Honecker's Children; Taylor, Let's Twist Again.
} 
political and scientific potential, giving them a sense of empowerment and self-worth in the very process of integrating them in the socialist and national collective..$^{42}$

Interviews suggest that teachers often assigned roles based on the student's talent, an act that was simultaneously a form of recognition, encouragement, and adult imposition. Most early teens entered expert positions with a mixture of playfulness and earnestness, being eager to prove themselves. Reflecting on the blurred border between child play and adult assigned duty, Cristi commented on his team's experience in 1973:

It is great when you can simultaneously play and accomplish relatively serious tasks. For us, this felt very much like child's play. We were each appointed tasks we really enjoyed. If they asked me, for example, to write the diary, nothing would've come of it. But Maria was really talented and she truly enjoyed writing. The fact that the diary turned out well and she was praised for it was wind at her back. ${ }^{43}$

The active effort that teen diarists, ethnographers, and historians put into perfecting ideological and scientific skills suggests a need to recalibrate our conception of agency. If agency is not exclusively envisioned in terms of freedom from constraints (whether political, ideological, or social), it can be enlarged to encompass a range of historically-specific actions that endow subjects with the necessary skills to seek accomplishment, including behaviors associated with inertia and passivity such as the practices of mentorship in ideological literacy and scientific expertise encouraged by socialist pedagogy. ${ }^{44}$ The next section will explore at length the discursive practice of diary writing.

\footnotetext{
${ }^{42}$ For an account of the origins of the revolutionary view of children as precocious activists in the Soviet 1920s, see Catriona Kelly, Children's World: Growing Up in Russia, 1890-1991 (New Haven, 2007).

${ }_{3}$ Group interview, Baia-Mare, July 2010. Cristi was thirteen years old when he participated in an ethnographic expedition in 1973. Partly because he came from a family of doctors, he was appointed the role of first aid assistant. ${ }^{4}$ I draw here on Saba Mahmood's critique of the analytical limits of liberal conceptions of agency, which equate agency with processes of subverting or opposing structures of domination and social norms in pursuit of autonomy and self-interest, ignoring the various ways in which dominant norms are "inhabited," lived, or aspired to. See Saba Mahmood, Politics of Piety: The Islamic Revival and the Feminist Subject (Princeton, 2005), 22-23, 29, $153-88$.
} 


\section{Discursive Performances of Socialist Patriotism: Ideological Literacy and Agency}

Official regulations instructed teams to appoint a diarist to record their experiences "accurately, in a succinct but expressive manner," in a collective diary or travelogue (jurnal de bord) ${ }_{{ }^{45}}$ On return from the expedition, diaries were first submitted to the county councils of the Pioneer organization, which sent the most accomplished diaries to the national jury in Bucharest alongside a photo album and relevant research collections. Integrating visual snapshots of the trip with written accounts, the diary was the only record of the expedition and the main guarantee of its authenticity. Suggestively named "the mirror of the expedition," the travelogue was to be completed during the trip, accruing evidence of collective activities and national sentiment.

Interviews and visible "correcting" interventions in the text (erasures, elisions) indicate that expedition diaries were often the result of a collaborative effort, undergoing a censoring process before submission (See Figure 1). The most common editing authorities were teachers and parents who joined in the effort to give diaries a politically-correct discursive form and fix grammar or vocabulary mistakes. Teachers in particular realized that diaries were read not only as child productions, but also as evidence of their political credentials that could have serious consequences on their career. Some diaries I consulted, but excluded from my analysis, indicate an extreme degree of adult intervention that essentially elides child participation: they are submitted in typed rather than hand-written format or exhibit a neat, adult hand-writing and a fluent, scientifically-elaborate, and grammatically-flawless language. ${ }^{40}$ This practice became more common in the mid to late-1980s in response to the crystallization of the discursive regime of late socialism, which permitted little deviation from its formulaic language.

Acknowledging the degree of adult intervention is relevant because, as historical or social actors, children have been traditionally spoken for, making it difficult to recuperate their voices. This common adult mediation was further augmented in socialist regimes such as Ceauşescu's Romania by the imperative of ideological correctness repeatedly enforced by institutionalized

\footnotetext{
${ }^{45}$ Regulations for pioneer expeditions published in Cutezătorii, May 15, 1969.

${ }^{4}$ In general, my analysis is based on diaries produced by teams whose members I could interview in order to enable

a comparative perspective on the expedition and the diary.
} 
and self-censorship. It is important to note, however, that severely-doctored diaries rarely won their teams awards, especially not during the 1960s and 70s, when competition organizers emphasized the importance of "authenticity." Authorities sought to discourage the practice of adult intervention, noting in official guidelines that "diaries written after the completion of the expedition or produced by teachers or parents will not be accepted by the jury." ${ }^{47}$ The conventions of authenticity governing the production of diaries thus made excessive ideological correctness suspect of adult intervention. Since expeditions were envisioned as training grounds for future communist citizens, the implication was that children were not fully proficient in official ideology and would acquire the desired fluency in the course of writing the diary.

My interviews offer a similarly balanced picture, indicating that adults usually worked with the child's text, correcting, adding, and giving finishing touches. A teacher from a rural area suggested that he often edited diary accounts since his pupils generally "lacked the rich vocabulary and literary talent of urban children." ${ }^{48}$ Asked how she selected the chronicler, a teacher of Romanian literature from Bucharest singled out the diarist's literary talent, but also readily acknowledged her role in "stimulating" the diarist to give a polished account of the expedition. Interestingly, teachers perceived their guidance as a natural part of the writing process, which would enhance rather than curb their students' writing skills:

Of course, Maria [the child diarist] enriched some passages later because one can't expect to give a full account 'on the go.' The lived experiences (trăirile) were certainly fresh, but the language could be further polished. While I was revising the journal, page-bypage, I would always urge her, 'How about this passage? How else could you phrase it?' So that the account would be as authentic as possible. ${ }^{49}$

While often edited by adults, expedition diaries are nevertheless extremely revealing sources that cannot be simply discarded as ideologically-falsified expressions of children's "genuine" experiences. As I argue in this article, they serve as evidence of the dialogic process through which children acquired ideological literacy and discursive authority in conversation

${ }^{4}$ See Cutezătorii, March 18, 1971. The organizers did not clarify how the distinction between child and adult productions would be made. In the early years of the competition, expedition members were also required to mail the diary to the national jury in Bucharest on the last day of their expedition from the first locality with a post office. ${ }^{4}$ A.M., interview, Năpradea, Sălaj ,July 2010. A.M. is a teacher of geography in the village of Năpradea, Sălaj.

S.V., interview, Baia-Mare, June 2010. S.V. was a teacher of Romanian in Baia-Mare. 
with their adult mentors, socialist ideology, and prewar national discourses. Bearing the marks of adult and social intervention, expedition diaries are "dialogical" discourses in the Bakhtinian sense of the concept. To the extent that they did not only refer to the actual expedition experience, but also to "another's speech," relying on and being oriented towards the highly standardized ideological discourse of the socialist nation, they are examples of "double-voiced discourse. ${ }^{{ }_{50}}$ Actively encouraged by their adult mentors to use a wide array of sources of inspiration in preparation for their task, diarists were trained in the practice of appropriating patriotic discourses of both socialist and pre-socialist provenance, a practice that Yurchak aptly calls "citationality" and attributes to the hypernormalization of authoritative discourse in the post-Stalinist period. ${ }^{51}$ Young chroniclers, for example, consulted other teams' expedition journals, read traditional historical and ethnographic accounts of the places visited, anthologized and integrated in their prose "beautiful expressions" from classics of national literature, and learned the art of emplotment from socialist children's literature. An indication that "citationality" was not considered incompatible with individual talent and authenticity is the fact that diaries often acknowledged the practice (See Figure 2).

The resulting diaries read like a collage of genres. For the most part, they present dense narrative accounts of daily team activities: waking up early, preparing breakfast, braving poor weather in the mountains, dividing tasks, playing football and volleyball, watching movies in local schools and cinemas, or encountering foreign tourists..$^{52}$ Drawing on the familiar genre of socialist children's literature abounding in their textbooks, diarists often frame these narratives as morality tales with pioneers cured of selfishness and homesickness by integration in the collective or comic skits on failed cooking attempts that left the entire team hungry.53 At times, diaries switch to scientific discourse, likely transcribed from museum brochures or guidebooks consulted before or after the expedition. Finally, in keeping with the increasingly lyrical

\footnotetext{
so Mikhail Bakhtin, Problems of Dostoevsky's Poetics, Ed. and trans. Caryl Emerson (Minneapolis, 1984$), 185$.

si Yurchak, Everything Was Forever, 36-76.

${ }^{s 2}$ Movies included American series such as Mannix in the early 1970s.

${ }^{s}$ Interviews often confirmed such memorable episodes, indicating that discursive representations were not mere

fabrications even when they were cast in recognizable socialist frameworks of values and morality.
} 
character of Ceauşescu's ideology of the socialist nation, diarists often indulge in poetic effusions of emotion on the national past, the beauty of the nationalized landscape, or the camaraderie of the collective..$^{54}$

As signs of genuine actualization of ideological imperatives by children who were not fully proficient in the discourse of socialist patriotism, instances of ideological improvisation were tolerated in the unpublished versions of the diaries submitted to the national jury.s. Diaries are full of clumsy articulations indicating that the ideological discourse is not fully mastered yet and there are shifts from politically-correct discourse to a sort of "innocent child speech" recording anything from apparently irrelevant episodes, curiosities, meal recipes, to aspects of economic scarcity, food rationing, or power cuts. Throughout the 1980s, expedition diaries abounded in simultaneously comic and critical comments on economic scarcity, which emerged, ironically, as a major obstacle in the teams' narratives of socialist endurance and success. Team members dared each other to find something else besides canned fish in local stores or come up with innovative substitutes for bread, which was rationed in the countryside.

Alternatively, diarists drew on the socialist regime's discourse of welfare provisions for children, assuming a critical position towards shortages. They complained about the difficulty of procuring expedition supplies, the indifference of school officials to pioneer endeavors, or the failure of local authorities to provide basic necessities for socialist citizens. Following her description of the team's visit to a hydroelectric power plant on the Dâmboviţa River in the consecrated language of socialist progress in 1989, a diarist commented critically on the dire results of rationing policies in the visited villages: "Children tell us that none of the twenty houses in the village has electricity; that they don't have either electric light or TV sets and use only battery-powered radios. And yet, we know that the Dâmboviţa provides electric power in

\footnotetext{
${ }^{s 4}$ On the distinctively lyrical character of Ceaușescu's ideological regime, see Paul Cernat's contributions in Paul Cernat et al., Explorări in comunismul românesc. vol. 1, 2, 3 (Iasi, 2004, 2005, 2008).

s As we will see later, instances of ideological clumsiness were flagged by jury members and edited on publication in the pioneer press, but were rarely penalized. On the contrary, many teams with flagged passages went on to receive national awards.
} 
this area. Why is it, then, that the children of this village do not benefit from it?" ${ }_{56}$ As a consequence, the superlative discourse of socialist achievement coexisted uneasily, in many diaries, with journalistic-style reports and critical assessments of economic shortages.

Instances of ideological clumsiness emerged in other situations as well. For the most part, diaries of ethnographic expeditions documenting visits to churches and monasteries referred to religious establishments as historical or cultural sites. The expectations of authenticity and originality, however, encouraged some diarists to engage in lyrical musings that exceeded the limits of ideological propriety. Following the team's visit to a church cemetery in 1973, a diarist indulged in existential reflections on the meaning of life, but failed to provide any ideologicallyappropriate answers: "Our questions weighed heavier than our backpacks. We were all meditating in silence. We were asking questions that have no answer. We kept asking "why," "why," "why"? Why do people die? Why do people live? What's their purpose in this world?"

The room for rhetorical maneuvering was further enlarged by the nationalist turn in the symbolic regime of socialist Romania, which opened the spectrum of available discourses beyond the strictly party-focused propaganda to patriotic rhetoric with a long tradition in Romanian culture. From the revolutionary literature of the militant 1848 -ers, diarists learned that the invocation of historical figures or the contemplation of natural landscape as a theater of national history could be expressive vehicles of national emotions of pride and belonging. Nineteenth and twentieth century Romantic poetry was similarly instrumental in providing diarists with a range of idyllic or militant visions of the peasantry. Villagers encountered on historical or ethnographic expeditions were commonly represented as timeless repositories of national traditions, giving diarists the opportunity to discursively align themselves with a collective defined in ethnonational terms. The following diary excerpt recounts the experience of two teenage girls, the team's diarist and ethnographer, as they tried on folk costumes offered by a

"Team "Flora," Târgovişte, "Diary of Expedition along River Dâmboviţa," (1989). Archive of the "Sports and Tourism Club" of the former Pioneer Palace, Bucharest (currently the National Children's Palace) [hereafter, APPB]. The materials in this archive were collected by and consulted courtesy of Victor Constantinescu, the administrator of the "Sports and Tourism" club.

${ }^{57}$ APPB, Team "Piatra Piţigoiului" (The Magic Stone), Baia-Mare, "Diary of Ethnographic Expedition in Ţara Lăpuşului” (1973). 
peasant woman as gifts. According to the elaborately-described encounter, the acts of wearing traditional attire and joining villagers attending the church ceremony triggered in the diarist an instance of identification with ancestors across centuries:

Her dark face was wrinkled with hard work, her hands were chopped, and there was a spirited sparkle in her eyes that mesmerized us. If I ever felt happy, it was at that particular moment. And I will never forget it because I do not know when I will ever again feel one with my ancestors, with Horea, Cloşca and the unforgettable heroes of Moisei. Maybe never again... Dressed up, each with a flower in our hands, we were walking on both sides of the woman but we were feeling somehow different, happy, proud. There were a lot of people in the street dressed in folk costumes..$^{58}$

While this elaborate passage was likely embellished with the help of a teacher, it reflects both a widespread view of the peasantry and the common practice of dressing in folk costumes and participating in village ceremonies on expeditions. Team members also evoked this memorable episode during my group interview, indicating that discursive representations were not divorced from experience, even when they were polished for the benefit of the jury. As we will see, dominant cultural representations were not confined to the pages of the diary, actively shaping how child participants made sense of the rural world. Most importantly, the passage is suggestive of how lyrically-inclined diarists could derive discursive authority from the process of aligning the self with the collective. The act of invoking a national community of ancestors invested diarists with wider significance, empowering them to stand metonymically for the collective and speak in its name.

Given its scripted form and collaborative creation, was diary writing a form of ideological indoctrination that precluded discursive agency? ${ }^{59}$ The demanding process of appropriating patriotic and scientific discourses or learning to align the self with a larger collective was anything but passive. Teen diarists did not compliantly absorb and reproduce ideological scripts, but showed dedication, hard work, and creativity in the process of cultivating literary and ideological skills. To quote a former pioneer turned writer after 1989, producing

\footnotetext{
ss Ibid.

${ }^{s 9}$ Most scholarship on ideological practices for youth focuses on their indoctrinating effect. See Paul Cernat et al., Explorări; Radina Vučetić, "ABC textbooks and Ideological Indoctrination of Children: 'Socialism Tailor-made for Man' or 'Child Tailor-made for Socialism'?," in Slobodan Naumović and Miroslav Jovanović, eds., Childhood in South East Europe: Historical Perspectives on Growing Up in the 19th and 20th Century (Münster, 2004).
} 
discourses on patriotic themes was a form of "DJ-ing" and the resulting text a creative act of "bricolage:"

I basically turned into a DJ because I would take a pile of books, mostly but not only poetry, that addressed the respective theme and cut out passages from prefaces, combining them. The result was a sauce of sorts. [I was] showing off, playing at stitching these diverse texts into a bricolage. ${ }^{60}$

Indeed, teachers often chose diarists who showed literary and ideological promise, enforcing a gender division of labor as they systematically selected older girls of twelve to fourteen, believed to have the necessary resources of lyrical emotion, talent, and maturity for systematic and creative writing.

Nor was diary writing, as the scholarship on discursive hegemony indicates, only a means through which children learned to "speak Bolshevik," acquiring an ideological skill they could deploy tactically in interactions with socialist authorities. ${ }^{61}$ Aligning the self with the socialist and national collective was not just a calculated trade-off to impress the national jury, but also a discursive strategy that empowered youth to stand metonymically for their team or nation. Ideological discourse was thus not only inescapable, but also enabling. Retrospective reflections on the practice of diary writing suggest that diarists derived a sense of discursive authority, selfworth, and literary accomplishment from "showing off" their mastery of authoritative discourse. Diarists recounted the sense of pride at being appointed team chroniclers or the feeling of guilt when they failed to write consistently, emotions that were likely enhanced by the promise of national awards and recognition.

Although diarists were essential to the success of expedition teams, teens also played a wide array of other roles. The next section will explore children's performances of expert roles on the most popular research ventures: historical and ethnographic expeditions.

"C.M. (b. 1973), email exchange/interview, June 2013.

"For an analysis of the process of learning to "speak Bolshevik" in Stalin's Russia, see Stephen Kotkin, Magnetic Mountain: Stalinism as a Civilization (Berkeley, 1995), 198-237. This classic study revolutionized approaches to ideology by exploring both its hegemony and everyday uses. 


\section{Social Performances of Socialist Patriotism: Playing Expert Roles}

Historical expeditions took many forms. Some followed the model of school trips, relying heavily on expert guidance and the consumption of ready-made historical narratives, being spiced up with visits at museums, monuments, birthplaces of famous historical or cultural personalities, and legendary places of historic battles (See Figure 3). These ventures best reflect the socialist regime's attempt to standardize memory sites in order to ensure that the resuscitated national past would not haunt the socialist regime. Playing its role in this effort of centralization of memory, the Pioneer Organization issued guidebooks of relevant historical sites that were recommended for scientific expeditions and school tourism more broadly. ${ }^{62}$

Alternatively, there were historical expeditions that employed an investigative method of doing history, featuring pioneers as detectives that filled in the blanks in the historical record. Some teams aimed to retrace by foot historically-relevant mountain routes such as those covered by conquering Roman armies during their invasion of ancient Dacia. Others walked in the footsteps of eighteenth century Transylvanian peasant rebels - Horea, Cloşca and Crişan - from the place of their arrest by Austro-Hungarian authorities to that of their execution and subsequent martyrization as national heroes. ${ }^{63}$ My survey of expedition routes reveals that the teachers' interest in local history combined with limited resources resulted in the research focused on the teams' own village or historical region. Interviews with organizing teachers indicate that regional research was also enhanced by collaboration and mutual help among teams from neighboring villages or counties. ${ }^{64}$ Oftentimes, these historical routes were relatively familiar and inconspicuous areas in the pioneers' native county, but expeditions invested them with historical significance, eventually turning them into symbolic local geographies. Tracing the route of Roman armies, members of team Dacia Felix from the Transylvanian county of Sălaj were

\footnotetext{
${ }^{62}$ See, for example, the travel guides authored by members of the national jury: Ion Vlăduţiu, Turism cu manualul de etnografie (Bucharest, 1976); Dumitru Almaş and Ioan Scurtu, Turism cu manualul de istorie (Bucharest, 1973).

${ }^{6}$ Ilie Popescu, "Dacia Felix:" 35 de ani de istorie si turism, 1972-2007 (Zalău, 2007), 12-13.

"Ilie Popescu, a teacher of history who led team "Dacia-Felix" (Sǎlaj), collaborated closely with his colleague from a neighboring village, Aurel Medve, who led team "Samus 2000," and with fellow historian Viorel Manolescu, leader of team "Sargedava" (Hunedoara). Popescu and Manolescu had been college friends and shared an interest in ethnography and Daco-Roman history, helping each other design routes throughout the 1970s and 80s.
} 
encouraged to think of their birthplace as the northernmost border of ancient Dacia and of themselves as Dacian descendants. ${ }^{65}$ Although the competition promoted local initiatives, these often betrayed centrifugal tendencies, encouraging regional rather than national pride and belonging.

Investigative methods of doing history also brought experiential learning, which was initially applied to the study of natural sciences, to historical research, where it translated into a decidedly empiricist approach to learning and positivist attitude to historical phenomena. Focused on the reconstruction of past historical experiences and the accrual of evidence in support of national narratives of unity and continuity, experiential learning turned children from passive receivers into active producers of history. Led by their history teacher, members of team Dacia Felix proved extremely adept at gathering historical evidence in the form of artifacts and testimonies. The team acted out its interest in Dacian and Roman civilization by participating in archeological diggings at sites in Sarmizegetusa, Costesti, and Porolissum throughout the 1970s and 80s. Pioneers were hosted at the archeologists' headquarters, working under the guidance of famous historians and archeologists. Their efforts culminated in the successful discovery of Dacian and Roman artifacts, which continue to be proudly exhibited in the local school museum in Chendrea to this day. ${ }^{6}$

In later years, team "Dacia Felix" further pursued its research on the topic of Dacian origin and ethnonational continuity by conducting small-scale oral history projects with villagers believed to be the direct descendants of Dacian ancestors (See Figures 4 and 5). ${ }^{67}$ During their weekly meetings in the school's Tourism and History club in the months preceding the expedition, pioneers explored the theory of continuity by consulting ethnographic studies of mountain areas such as Ţinutul Pădurenilor by ethnologist Romulus Vuia, who in the interwar

\footnotetext{
"Team "Dacia Felix," Jurnal de Bord al echipajului “Dacia-Felix" (1973), 5, 9-10. Archive of the "History and Tourism School Club, 1972-2007,” [hereafter ACS], village Chendrea, Sălaj county.

${ }^{\infty}$ I visited the school exhibition in the village Chendrea in Salaj in the summer of 2010, when I was conducting interviews with former team members. The endurance of the exhibition is more important for the purposes of this study than the actual value of the exhibits (whether they are genuine Dacian and Roman artifacts), being testimony to the importance participants attached to pioneer exhibitions and their accomplishments (awards, collections, diaries, etc.).

" ACS, Team "Dacia Felix,” Jurnal de Bord al echipajului “Dacia-Felix” (1988 and 1989).
} 
period argued that ethnographic studies of folk costumes and rural architecture can compensate for the lack of archeological evidence of Dacian civilization. ${ }^{68}$ Child historians found inspiration in a set of two images included in Vuia's chapter on traditional village costumes: the first reproduced a section of Trajan's Column in Rome featuring Dacians in traditional attire, while the second reproduced Vuia's photograph of villagers from Ţinutul Pădurenilor wearing hooded attires in the interwar period. The implication was that, given the similarity of the attire, the villagers were descendants of the Dacians represented on Trajan's Column.

Fifty years after the study, both Trajan's Column and Vuia's photographs had become reified into evidence. During the expedition, pioneers visited the village mentioned by Vuia, interviewing villagers in their 80 s to identify the peasants in the photo by name. Both my recent interviews and the 1989 diary suggest that old villagers confirmed the thesis of continuity, apparently recognizing their grandfathers in the pictures and entertaining child-historians with elaborate stories about their ancestors' destiny. Having successfully established the link between ancient Dacians, interwar peasants, and contemporary villagers, pioneers acted as active producers of historical narratives of millennial continuity on Dacian territory. The fact that children accomplished these goals in their quality of team historians or archeologists further enhanced their personal investment in collective narratives, an investment that continues into the present day, when former team members express pride at their historical achievements.

Teachers and pioneers also mobilized ethnography in the service of national history, appropriating the resources and rhetoric of the competition to conduct personalized expeditions in highly symbolic ethnographic areas such as Ţara Maramureşului, Ţara Lăpuşului, Ţara Moţilor, Ţinutul Pădurenilor or Ţara Haţegului. Although some of these sites were officially promoted by the Pioneer Organization through publications or guidebooks, interviews suggest that ethnographic efforts were also intensified by the tangible threat posed by the regime's modernizing efforts toward the old world of the village and its traditions. Throughout the 1970s and 80s, when Ceauşescu's regime was engaged in a domestically-reviled campaign for "the

${ }^{\star}$ The edition mentioned in the pioneers' diary is Romulus Vuia, Studii de etnografie si folclor, vol 1 (Bucharest, 1975). 
systematization of the countryside" by tearing down entire villages to replace them with modern facilities, some teachers led child ethnographers up mountain routes in an attempt to unravel peasant universes that had thus far withstood the transformative efforts of the regime.

Engaged in an ethnographic expedition less than thirty miles south of their native town, a pioneer team from Baia-Mare described the decision to explore Ţara Lăpuşului in a language that relegated the area to a different temporality. To construct the village world as a legitimate object of ethnographic research, pioneers and their teachers employed a time-distancing device "allochronism," or the "denial of coevalness" - that is central to anthropological discourse:"9

Our expedition was born out of the desire to observe and study the folk costumes, habits, and life of people in Ţara Lăpuşului. We wanted to travel beyond the confines of our everyday life, to a beautiful landscape without apartment buildings and factory chimneys. Our desire to escape noisy streets and cars took us to a new world ... of people whose traditions could not be affected by the passing of time or by the changes that spread like the tide over the entire country. ${ }^{70}$

Banishing the village from linear historical time, including the implicit teleological drive to communism promoted by socialist historiography, the diary relied on national idioms of presocialist provenance, activating the tension between modernity and tradition inherent in the ambivalent ideology of the socialist nation. This is further evidenced by the authorities' reaction to the ideological dilemma posed by the diary: while the opening passage was edited on publication to avoid the implication that rural areas were not transformed by socialist progress, the expedition team was rewarded with the highest national prize in $1973 .^{71}$

Retrospective recollections indicate that, far from being a mere rhetorical flourish relegated to the diary, the idea that researched villages were surviving oases of century-old folk traditions was shared by many expedition participants (See Figures 6 and 7). One of the team members From Baia-Mare, for example, remembered his sense of excitement at venturing into Ţara Lăpuşului: "It was the first time I set foot in the world of the village, which is an absolutely

\footnotetext{
${ }^{*}$ Johannes Fabian, Time and the Other: How Anthropology Makes its Object (New York, 1983).

${ }^{70}$ APPB, Team "Piatra Piţigoiului," (1973).

"Excerpts from the diary were published in Cutezătorii, January 9, 1975. The team won both "The Golden Pen," the award for the best written diary, and "The Golden Compass," the highest national award of the competition, being rewarded with a group trip to the Soviet Union.
} 
fascinating world and absolutely ... different for a city kid raised in an apartment building." ${ }^{2}$ Popularized by some expedition teachers as well as by the literature abounding in children's textbooks, this view was also likely embraced with earnestness because it legitimized the pioneers" "expert" roles. Child ethnographers cultivated an anthropological gaze that had the effect of exoticizing the village. To document the essential differences and specificities of this world, they practiced acts of direct observation and participation: they examined, documented and collected folk culture, joined in traditional village activities (fieldwork, weddings, or church going), interviewed villagers, and recorded folk music and language specificities (See Figures 8 , 9, 10). Even in retrospect, former expedition participants suggest that peasants were unaware of the treasures they harbored, implying that it took a trained eye to distinguish valuable from unworthy artifacts:

Cristi: We went from house to house asking for various objects, especially old folk costumes. To which, and this happened twice, they [villagers] would say 'I'll give you this new one' ...

Denis: They didn't understand why we wanted old attire [laugh]. ${ }^{73}$

The attributes of modernity, ranging from forms of scientific observation to notebooks, cameras, or audio recorders, bestowed scientific expertise on pioneers. Ultimately, this achieved an interesting inversion of roles as teens were empowered with the authority to reduce mature peasants to childlike dependency as objects of ethnographic research. Reflecting on this sense of empowerment, former expedition participants recall villagers' expressions of surprise - “Don’t you have parents?" - when large groups of seemingly unsupervised children approached them. This upset relationship is also reflected in diaries, where children practiced ethnographic writing, describing direct encounters with locals in a simultaneously celebratory and patronizing language that yielded an idealized image of the peasant as a "noble savage." An example of this language, the following diary excerpt focuses on the importance of experiential learning - having

\footnotetext{
"Group interview with members of the team "Piatra Piţigoiului," Baia-Mare, June 2010. The respondent is Cristi, quoted previously in this article. The fact that György Makara, a painter and teacher of drawing who led the team in the 1970s, could gather most of his former pupils for the interview thirty years after the events is testimony to the enduring closeness of the group. Ibid.
} 
dinner with the locals - in enabling pioneers to gain insights into the peasants' presumably uncontaminated and childlike nature:

At Costeni, we stopped by the river. This is how we organized ourselves: the ethnographers, the folklorists, the reporters and the captain's adjunct went from house to house to collect artifacts; the boys were in charge of dried wood and putting up the tents, the girls started cooking. Here, on this first night, we got to know the locals better. [They were] humble, as shy as children, but with an open heart and soul. They served us cheese pie. What a treat! While eating, I kept looking at their sun burnt but shiny and clean faces, at their hardworking hands, at their bare feet. ${ }^{74}$

Ultimately, historical and ethnographic expeditions did more than enrich children's knowledge of the past. In the process of performing expert roles, pioneers learned that national history was as objectively real as the treasures they unearthed and as unitary and coherent as the biographies they documented. For pioneer archeologists and ethnographers, history resided in objects, places, and people that could provide direct and unmediated access to the past. Whether it meant holding ancient artifacts in one's hand, walking the walk of national heroes, or talking to presumed Dacian descendants, experiential learning gave expeditions a foundational and essentializing character that textbook narratives could never hope to attain.

Experiential learning also significantly empowered youth. Central to the pedagogy of socialist citizenship, the practice of assigning teens to positions of leadership and scientific expertise was both constraining and enabling. Pioneer teams operated within certain ideological and methodological confines, ranging from scientific empiricism and positivism to the national imperatives of the time. However, it was these very ideological imperatives that empowered pioneers to master the social and historical world in the process of defining, interpreting and representing it as the object of their expeditions.

" APPB, Team "Piatra Piţigoiului," (1973). 
In launching Expediţile Cutezătorii, the Pioneer Organization aimed to engage teachers and their students in purposeful and patriotic tourism that would enhance their loyalty to the socialist regime, turning youth into educated and well-integrated socialist citizens. The competition was successful in attracting teachers and students, who met organizers halfway because they recognized expeditions as opportunities to achieve professional, communal, and individual satisfaction. What made this convergence of interests and values possible in a period generally described in terms of social cynicism and apathy? If seen from the perspective of the regime's ideological producers, the socialist ideology and pedagogy informing Expeditiile Cutezătorii appear monolithic and monologic, their inherent contradictions and polyphony become apparent from the perspective of their intended audience, the teachers and pioneers who interpreted and translated them into practice. The multivalence of the expeditions, which were popularized as both instances of socialist modernization and returns to tradition, both individualist and collectivist ventures, entertaining adventure and physical endurance, leisure and rigorous instruction, and scientific exploration and opportunities for civic and patriotic education, can explain their broad appeal among children and educators. Expediţiile Cutezătorii were certainly not unique in their multivalence among youth activities and can thus provide insights into how and why socialist citizens engaged with other state-promoted projects in meaningful and self-fulfilling ways.

Organizing teachers were genuinely energized by the state agenda of national reclamation and the promise of professional self-realization. Some teachers engaged in expeditions to secure career promotions, others because they were passionate historians, ethnographers, or mountain hikers, and quite a few combined passion with professional utility. Some teachers continued to organize expeditions after the collapse of the regime, extending the use of purposeful tourism to the renovation of religious sites or the reeducation of juvenile delinquents through works of social utility. ${ }^{75}$ Many current forms of educational entertainment, such as summer camps relying

\footnotetext{
${ }^{25}$ Victor Constantinescu, interview, Bucharest, March 2009. A number of former organizers petitioned the Ministry of Education for approval to launch a revamped national competition featuring new awards, but remaining largely modeled on the goals of patriotic and scientific education popularized under socialism.
} 
heavily on historical reenactments, echo the socialist pedagogy of citizenship in their focus on national belonging, collective values, and performativity. ${ }^{70}$

As the survey of expedition routes and research goals indicates, teachers also responded with enthusiasm because the ideological ambivalence of official ideology opened room for appropriation and personalization. Expedition teams often privileged the national over than the working class themes promoted by the Pioneer Organization. Constructing the village as an anthropological object of research, ethnographic expeditions succumbed to the idealization of the past, failing to make the desired connection with the socialist present. As most village or small town teachers were genuinely motivated by an interest in local history, many expeditions engaged children in regional projects. Rather than promote a broadly national imaginary, expeditions were more likely to enhance regional identification and challenge the regime's goal of national and social homogeneity reflected in the standardization of memory sites.

For their part, former child participants overwhelmingly remember pioneer expeditions as enabling rather than constraining state-imposed activities. Many teens developed genuine bonds of friendship that were strengthened by hardship, common goals, and separation from their families, often until long after the expedition. Positive experiences of collective life extended beyond their "gang" of friends to include feelings of regional or national pride and belonging. Aside from facilitating friendship and community, the socialist pedagogy of citizenship also gave teens a sense of self-worth and recognition by placing them in agentive positions as masters of ideological literacy or subjects of inquiry entrusted with unraveling the laws governing the social and historical world.

Responding to the socialist state's call to undertake purposeful and patriotic tourism, child and adult participants used state structures and resources, appropriated aspects of an ambivalent socialist ideology for individual and communal fulfillment, and actualized resources of agency inherent in the pedagogy of socialist citizenship. At times, their acts of appropriation

\footnotetext{
${ }^{76}$ Many of these events, such as the thematic summer camp "The Dacians and the Romans," where children dress up as ancient warriors and re-enact historic battles, are organized by younger generations of teachers, who were themselves pioneers in the 1970s and 80s.
} 
seemed to challenge the ideological and educational agenda of the regime. Few participants, however, envisioned expeditions as forms of opposition to or escape from the regime, making it problematic to approach them as sites of resistance. On the contrary, the enabling experiences expeditions generated were only possible through active engagement with state structures and the socialist and national values they promoted. Although they resented the increase in mandatory political chores and challenges of economic scarcity, children and teachers found common ground with the socialist state in prizing national allegiance, patriotic and scientific education, sociability and camaraderie, and professional self-realization. 


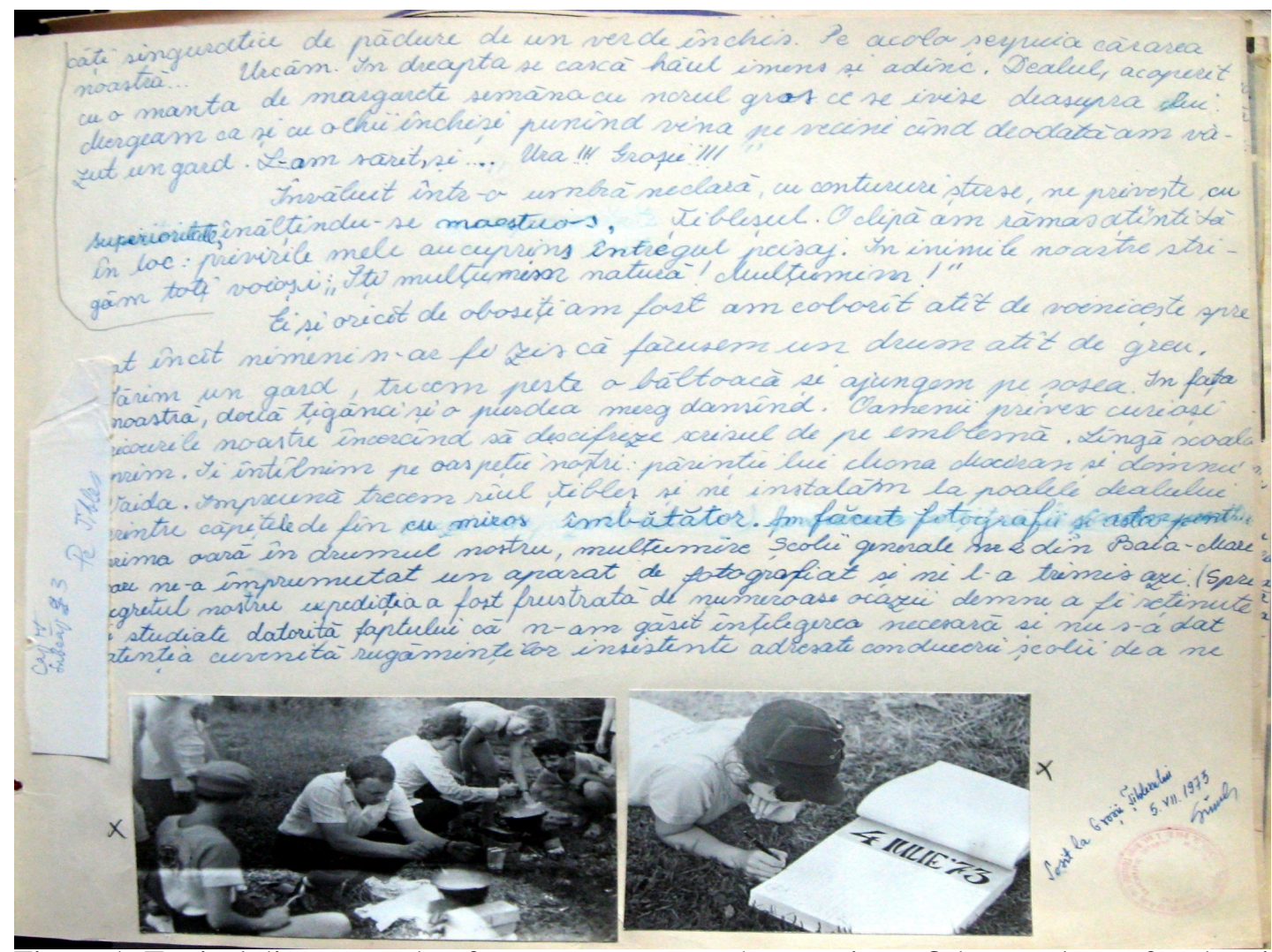

Figure 1. Typical diary page that features erasures and corrections. Other markers of authenticity include the stamp and signature of school officials in the village visited and a photo of the diarist in the process of recording expedition events (bottom right corner). APPB, Team "Piatra Piţigoiului" (Baia-Mare), "Diary of Ethnographic Expedition in Ţara Lăpuşului” (1973).

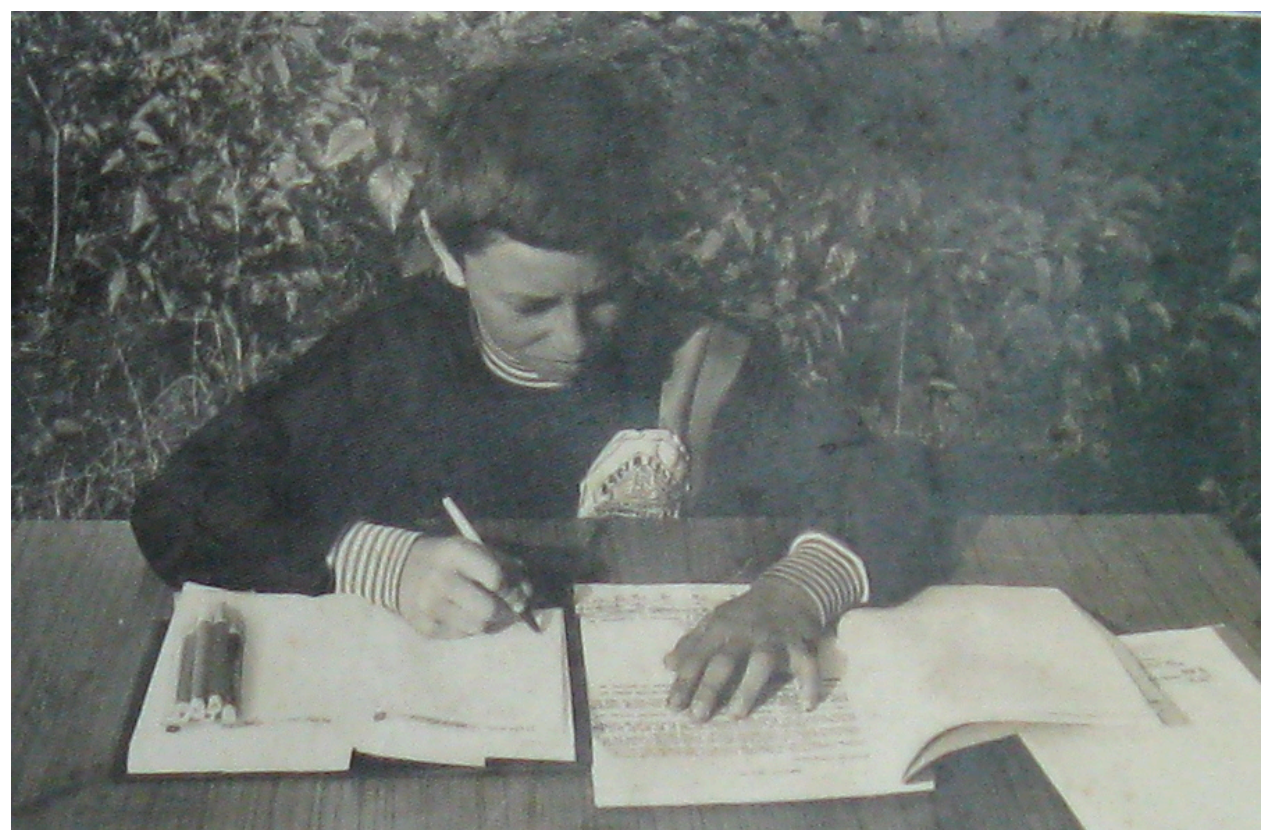

Figure 2. This photo features diary writing as an act of inspiration or transcription from other sources. ACS, Team “Dacia Felix,” Jurnal de Bord al echipajului “Dacia-Felix” (1989). 

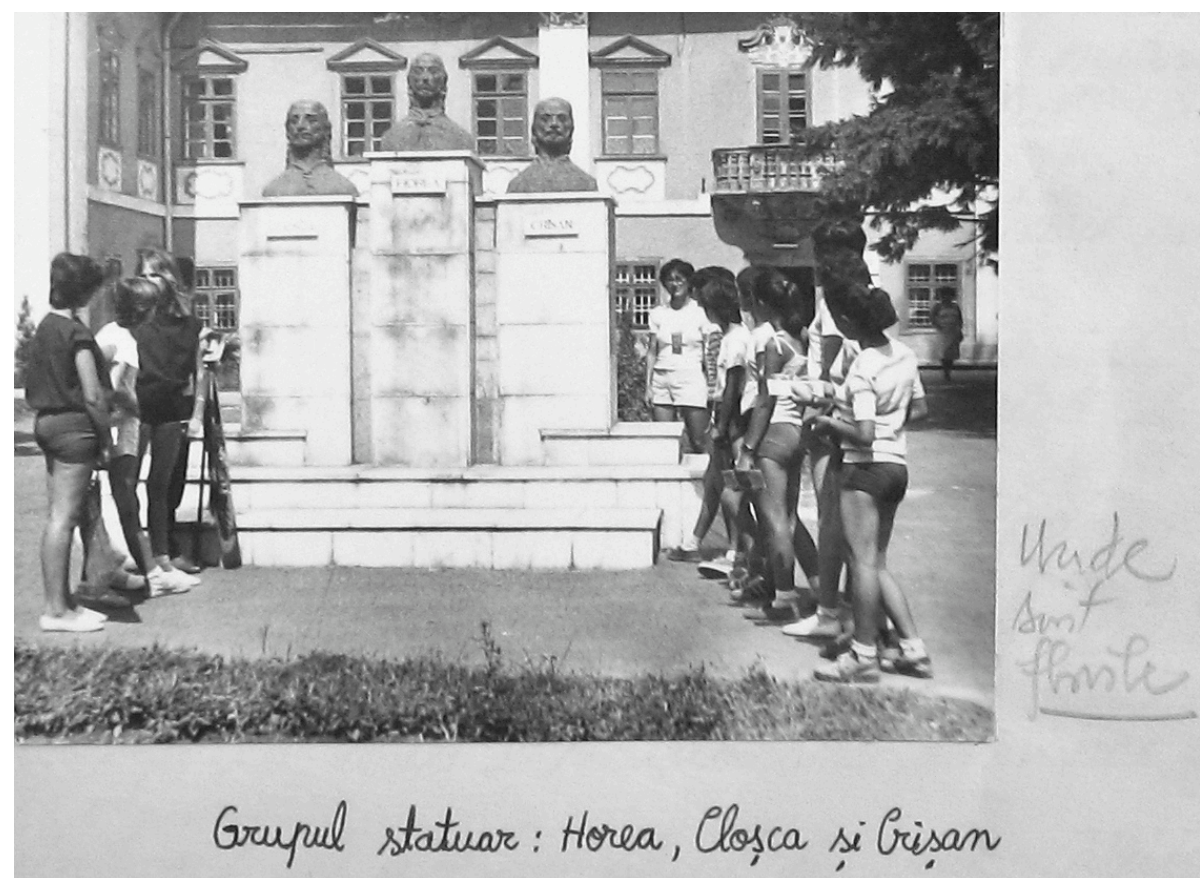

Figure 3. Members of team Dacia Felix visit the statues of eighteenth century Transylvanian peasant rebels - Horea, Cloşca, and Crişan in Deva. A jury member scribbled in the margins "where are the flowers?" suggesting the absence of a required performance of deference to national heroes. ACS, Team "Dacia Felix," Jurnal de Bord al echipajului "Dacia-Felix" (1988).

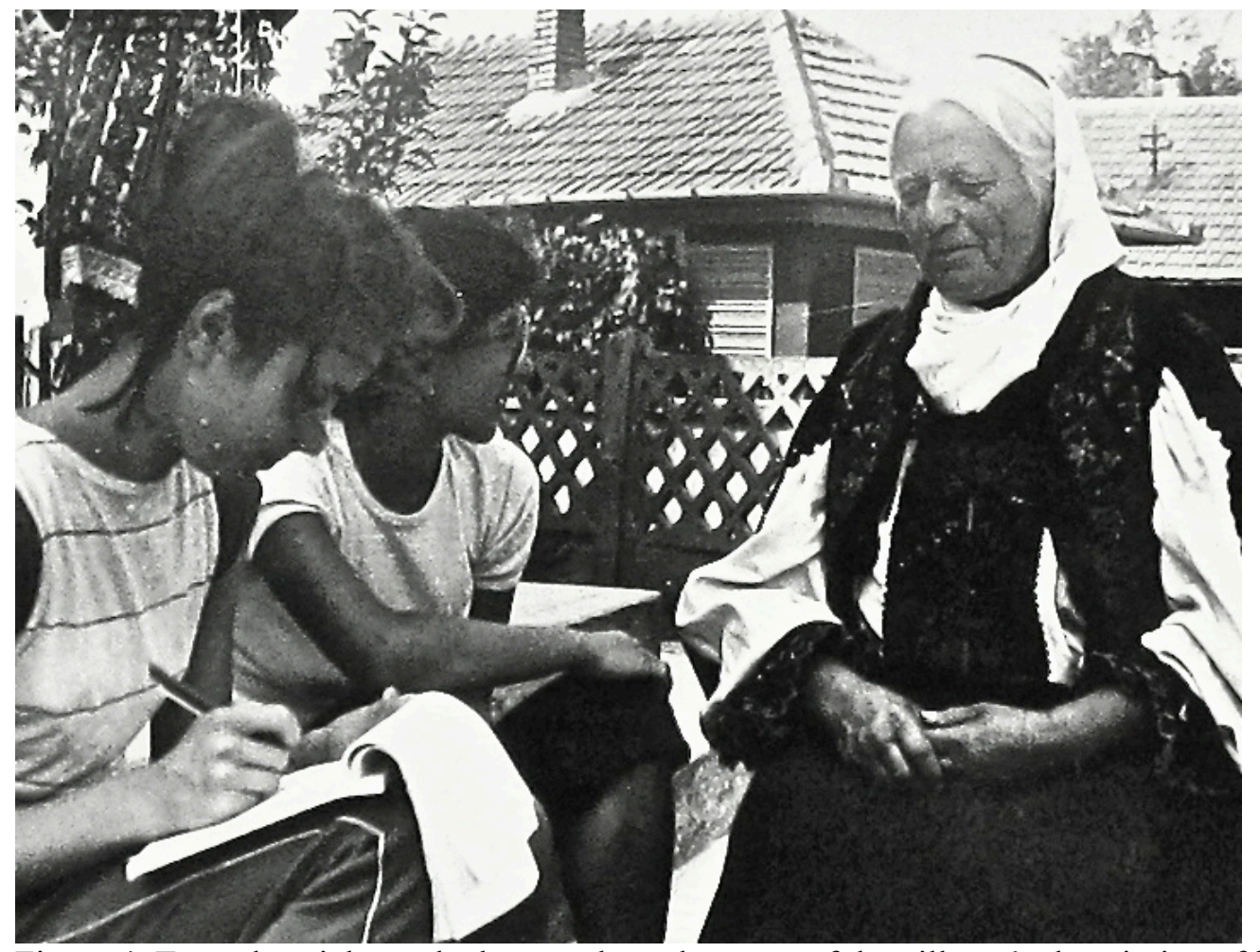

Figure 4. Teen chronicler and ethnographer take notes of the villager's description of local folk costumes, Lelese village. ACS, Team "Dacia Felix," Jurnal de Bord al echipajului “Dacia-Felix” (1988). 


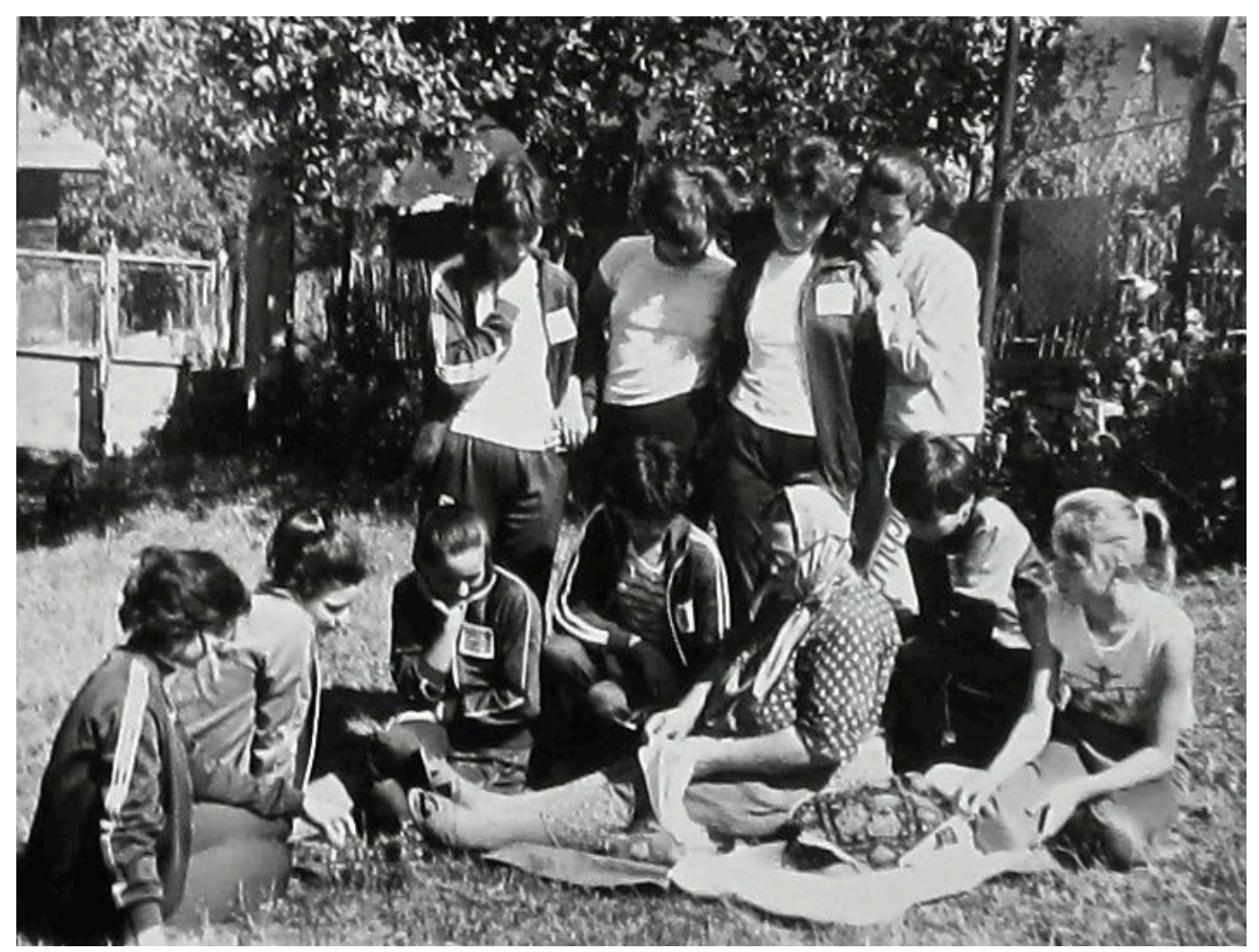

Figure 5. The team is treated to a demonstration of how folk costumes are decorated, Cerbăl village. ACS, Team "Dacia Felix," Jurnal de Bord al echipajului “Dacia-Felix” (1988).

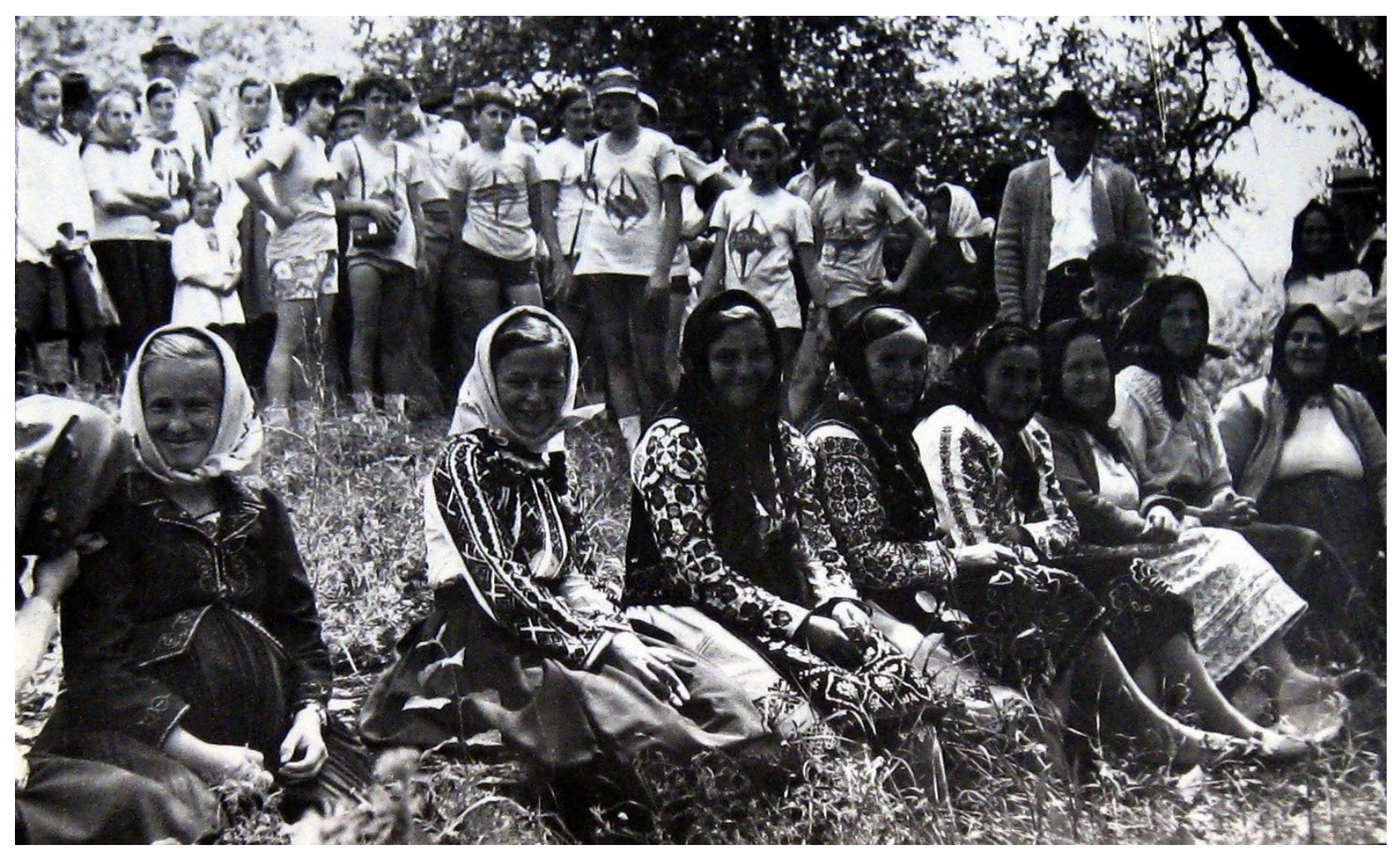

Figure 6. Pioneers (background) with villagers at the wooden church in Şurdesti on a Sunday, 1973. APPB, Team "Piatra Piţigoiului" (Baia-Mare), "Diary of Ethnographic Expedition in Ţara Lăpuşului" (1973). 


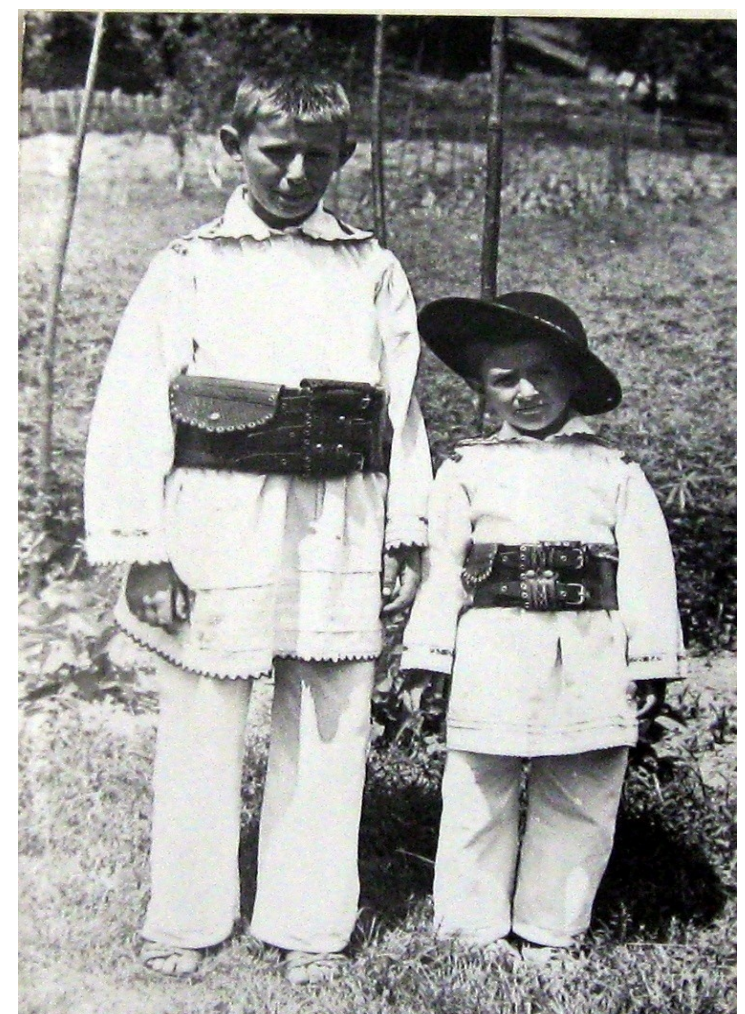

Figure 7. Documenting folk costumes. APPB, Team "Piatra Piţigoiului" (Baia-Mare), "Diary of Ethnographic Expedition in Ţara Lăpuşului” (1973).

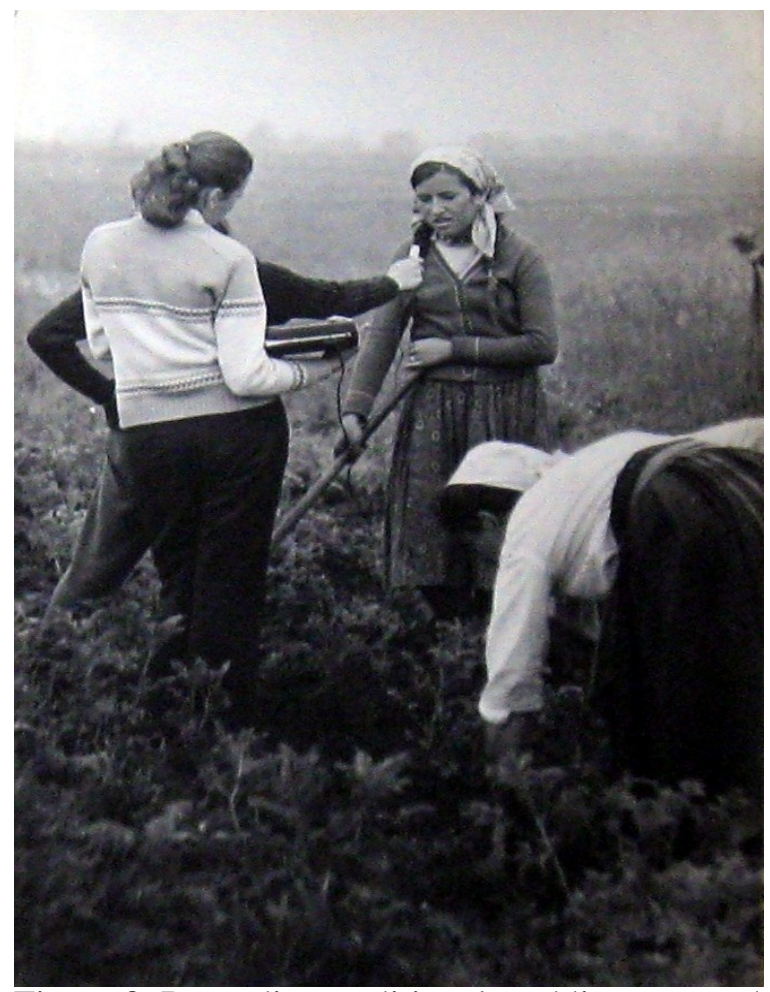

Figure 8. Recording traditional wedding songs. APPB, Team "Piatra Piţigoiului" (Baia-Mare), "Diary of Ethnographic Expedition in Ţara Lăpuşului” (1973). 

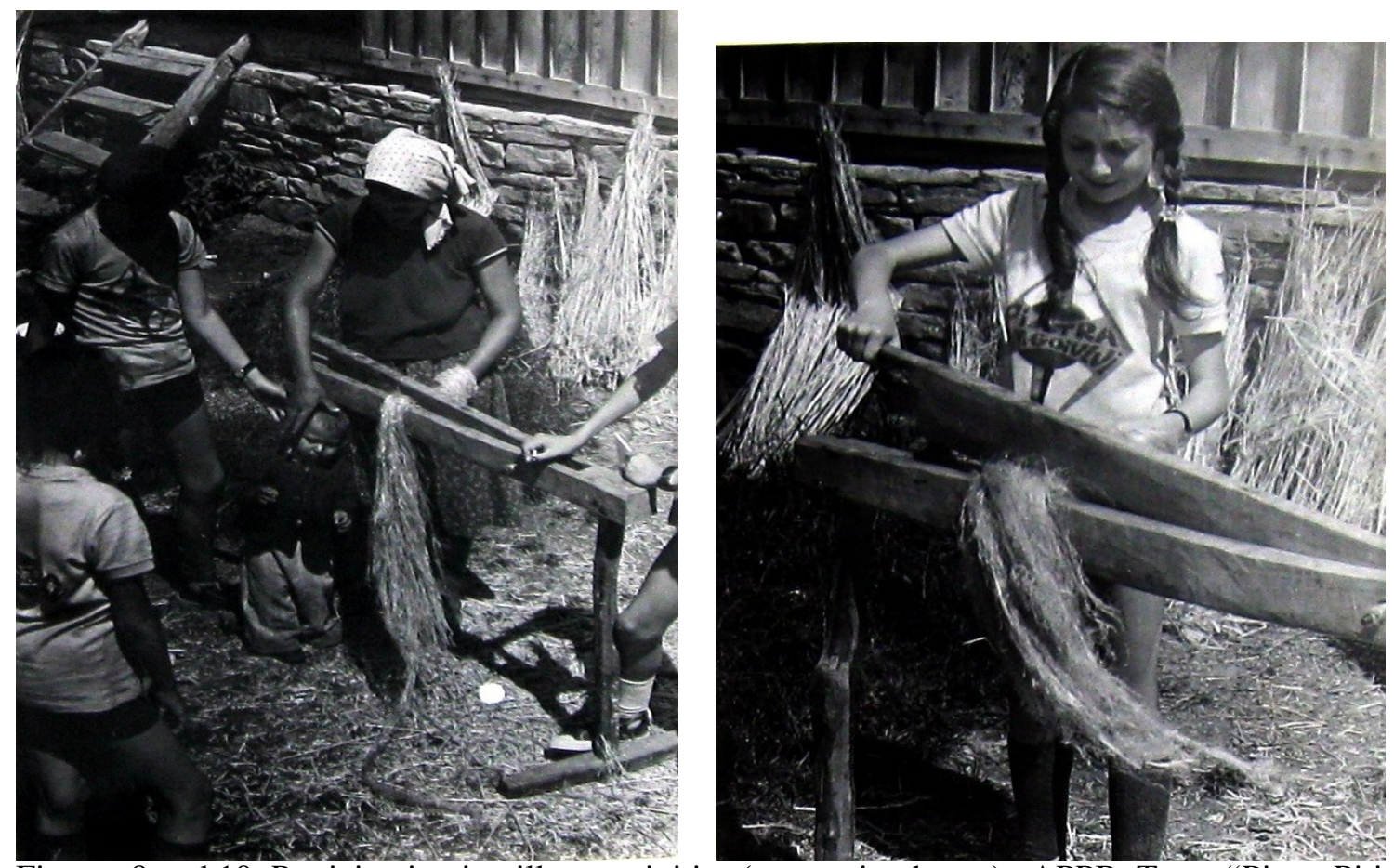

Figures 9 and 10. Participating in village activities (processing hemp). APPB, Team "Piatra Piţigoiului" (Baia-Mare), "Diary of Ethnographic Expedition in Ţara Lăpuşului" (1973). 